\title{
IUCN, National Parks, and Protected Areas: Priorities for Action
}

\author{
by \\ JEFFREY A. MCNEELY \\ Executive Officer, IUCN Commission on National Parks and Protected Areas \\ World Conservation Centre, Avenue du Mont-Blanc, 1196 Gland, Switzerland \\ $\&$ \\ Kenton R. Miller, Ph.D.(Syracuse) \\ Chairman, IUCN Commission on National Parks and Protected Areas \\ Director, Center for Strategic Wildland Management Studies, \\ University of Michigan School of Natural Resources, \\ Ann Arbor, Michigan 48105, USA.
}

\section{INTRODUCTION}

The 20th century has seen the most far-reaching ecological change in human history. Using readily-available sources of energy (petroleum and coal) from plants and animals that have long been extinct, Homo sapiens has expanded its ecological niche to such an extent that there has been a more-than-doubling of the total population of the species in the past few decades. What were once marginal habitats have been brought into food production by using new machines, new agricultural strains, pesticides, fertilizers, and social organizations - often producing for consumers living far away. Habitats of species which formerly were masters of their niche have been usurped in order to provide for the needs of the expanding human population.

For the first time in history, a single species has the capability of driving large numbers of other species to extinction. Informed estimates are that as many as a million species may be gone for ever by the turn of the century (Myers, 1980).

Equally, Man has it within his power to ensure that species and ecosystems are maintained as part of the human habitat. A major means of accomplishing this is through the establishment of national parks and other types of protected areas. It is therefore no coincidence that the International Union for Conservation of Nature and Natural Resources (IUCN) has been deeply involved with national parks from its very beginnings. This involvement has included:

- Publishing lists and directories of protected areas (IUCN, 1961, 1971, 1975, 1977, 1980a, 1982b, 1982d; Carp, 1980). The Protected Area Data Unit (PADU) was established in 1981 to computerize the data held by IUCN, and to promote greater application of those data.

- Publishing the quarterly journal Parks, now in its seventh year, with a circulation of some 7,000.

- Establishing the Commission on National Parks in 1960. Now enlarged to become the Commission on National Parks and Protected Areas (CNPPA), their body has a current membership of 258 from 89 countries.
- Publishing basic conceptual papers dealing with protected-area matters (IUCN, 1978, 1979, 1980b; Eidsvik, 1980; Poore \& Gryn-Ambroes, 1980; Lausche, 1981).

- Establishing a system of biogeographic provinces of the world (Udvardy, 1975), now widely used for assessing protected-area coverage and suggesting regions for priority attention.

- Cooperating closely with United Nations agencies involved in protected-area matters (FAO, UNEP, UNESCO), at both conceptual and field levels. This includes providing technical evaluations of natural sites nominated for the World Heritage List to UNESCO's World Heritage Committee (see IUCN, $1982 b$ ) and acting as the Secretariat for the Ramsar Convention on Wetlands of International Importance Especially as Waterfowl Habitat.

- Supporting field projects, especially in developing countries, aimed at establishing and managing national parks and protected areas. Funded primarily by the World Wildlife Fund, some 1,500 projects involving the expenditure of over $\$ 40$ million had been implemented in support of protected areas by the end of 1982. Countries with major programmes have included China, Costa Rica, Ecuador, India, Indonesia, Madagascar, Mali, Tanzania, and Zambia.

- Holding meetings in various parts of the world to promote protected areas. CNPPA holds two meetings per year, rotating among the biogeographic realms (see, for example, IUCN, 1980c, 1981). In addition, IUCN has organized major international meetings to discuss protected areas, including the First World Conference on National Parks in Seattle, Washington, in 1962 (Adams, 1964), the Second World Conference on National Parks in Grand Teton, Wyoming, in 1972 (Elliott, 1974), the International Conference on Marine Parks and Reserves, Tokyo, 1975 (IUCN, 1976), and the World National Parks Congress, Bali, Indonesia, October 1982 (IUCN, 1982d).

The Bali Congress was of particular interest because it was directed specifically at defining the role of protected areas in supporting social and economic development. Based on the philosophy of the World Conserva- 
tion Strategy (1980), the Congress sought ways and means for protected areas to contribute to development by helping to maintain genetic diversity, conserve ecological processes and life-support systems, and ensure that any use of renewable resources is sustainable. This paper will describe the process by which the Congress arrived at the new priorities, then present the major points of the Bali Action Plan (IUCN, 1982f) and describe IUCN's effort to help ensure that protected areas will play a permanent part in maintaining the human habitat.

\section{THE WORLD NATIONAL PARKS CONGRESS}

At its closing session, the World National Parks Congress issued a Declaration (printed on page 73 of this issue) for wide dissemination. This document provides the broad policy-framework to guide future action, based on the conviction that protected areas, when designed and managed appropriately, can bring major sustainable benefits to society; indeed, protected areas can play a central role in the social and economic development of rural environments, and can contribute to the economic well-being of urban centres and the quality of life of their inhabitants.

The Congress also showed that, as options are decreasing for choosing how the natural environment may be conserved, the scientific foundation of conservation has become more and more sophisticated. Island biogeographic theory, centres of endemism, minimum critical size, optimal design of reserves, population genetics, population dynamics, 'the new economics', and other advances relevant to conservation, have allowed those charged with the task of planning and establishing protected areas to determine, much more precisely than formerly, the requirements of design and management.

A major problem identified at Bali is that most protected areas were selected for reasons other than the objectives for which they are now managed, or were established before the scientific tools that are now at hand became available. A first priority in this regard is to ensure that, to the extent that may be possible, existing protected areas are capable of sustaining living resources; where the existing areas fall short of this basic objective, planners and managers must take the appropriate steps to remedy the situation while options remain open.

To establish priorities for the coming, critical years, the Congress prepared a series of 20 Recommendations (IUCN, 1982e). In addition, working groups from the world's eight biogeographic realms presented reports on priorities for each realm, and many of the case-studies and other presentations provided examples which should be emulated; the 'Future Directions' addresses from each realm were particularly pertinent in providing thoughtful analyses of future trends. Based on this material, the major points of an Action Plan were presented to the closing session of the Congress. Further work on the plan was done at the IUCN Secretariat by the present Authors. The resulting Bali Action Plan (IUCN, 1982f) is now being circulated widely to enlist support and develop projects for implementing the Plan.

\section{THE BALI ACTION PLAN*}

The Bali Action Plan recognizes that there are already competent government agencies in most countries whose responsibility is the management of national parks and other protected areas, and that each of these agencies is already carrying out a programme of work that is relevant to the needs and priorities of the country involved. However, the 450 specialists and others attending the Congress also recognized that there was a serious lack of understanding of management tools (biogeography, zoning, monitoring, training procedures, protected-area economics, etc.), that budgets are not always allocated to the most important priorities, that management plans are the exception rather than the rule, that relevant information is not flowing as well as it should do, that training is lagging far behind needs, and that government officials and the public generally undervalue the role of protected areas in environmentally-sound development.

The Bali Action Plan aims to provide guidance and assistance to those agencies which are interested in improving their own management effectiveness in meeting the objectives for which their protected areas were established. Clearly, this is not the work of the IUCN Secretariat alone; it must involve all parts of the Union - State Parties, Government Agencies, and Nongovernmental Organizations - as well as IUCN's major international partners in conservation: UNEP, UNESCO, FAO, and the World Wildlife Fund.

The ten interrelated and mutually-reinforcing objectives of the Bali Action Plan, with a brief background and summary of necessary activities, are as follows:

\section{Objective 1:}

TO ESTABLISH BY 1992 A WORLD-WIDE NETWORK OF NATIONAL PARKS AND PROTECTED AREAS, EXEMPLIFYING ALL TERRESTRIAL ECOLOGICAL REGIONS

Some 2,600 protected areas, covering nearly 4 million square kilometres, have already been established by 124 countries. During the $1970 \mathrm{~s}$, the number of protected areas increased by $46 \%$ and the total area protected increased by over $80 \%$ (Harrison et al., 1982). Impressive as these figures are, they still fall far short of the need.

Modern theoretical island biogeography (e.g. MacArthur \& Wilson, 1967) suggests that, as the area of a habitat is reduced, the number of species which will be supported by it is also reduced (and the populations of the species which do survive are likely to be reduced in rough proportion to the loss of habitat). Therefore, any reduction of habitat carries a degree of threat to the survival of some species.

Rather paradoxically, the increase in protected areas in recent years has been paralleled by an increase in land producing crops and timber; the area devoted to growing grain in developing countries, for example, increased from 2.2 million sq. $\mathrm{km}$ in 1950 to 4.1 million sq. $\mathrm{km}$ in 1981 , and there is no indication of the trend slowing

\footnotetext{
* Not to be confused with the much briefer 'Bali Declaration' printed on page 73 of this issue.--Ed.
} 
down, as increasing food-production feeds populationgrowth (Barr, 1981).

How much land should societies devote to conserve species and ecosystems? The above very condensed discussion of 'island' biogeography and trends in land-use allocation, makes it fairly clear that the answer to this question is as much political as biological. Biologists have already presented overwhelming evidence that species are becoming extinct at an alarming rate which is sure to increase in the coming years (Myers, 1980; Ehrlich \& Ehrlich, 1981), so it is now up to politicians (and all those who have influence on politicians) to decide how much land will be used for conservation (or, conversely, what level of species-loss is acceptable).

Countries have answered this question differently. Nine countries of over 20,000 sq. $\mathrm{km}$ area have over $10 \%$ of their land-area protected as national parks and reserves: they are Austria, Benin, Bhutan, Botswana, Central African Republic, Rwanda, Senegal, Tanzania, and Zimbabwe; countries with over $5 \%$ of their land protected include Chad, Ivory Coast, Japan, Malawi, New Zealand, Sri Lanka, Thailand, USA, Upper Volta, Venezuela, and Zambia. On the other hand Egypt, French Guiana, Iraq, Laos, North Yemen, South Yemen, Syria, United Arab Emirates, and Vietnam, have no protected areas at all (Harrison et al., 1982). These figures suggest that somewhere around $10 \%$ might be a reasonably optimistic target figure for many countries.

But this must be the right $10 \%$, identified and selected. on the basis of objectives of conservation and supporting development, of an appropriate size and shape, and covering the range of habitats which require protection. This will require the development of biogeographical classification systems with a flexibility of scale which can be used in the analysis of protected-area coverage at a variety of regional and national levels, and the detailed examination at the regional and country level of protected-area coverage; New Zealand has already provided an excellent example of this process (Dingwall, 1982).

\section{Objective 2.}

TO INCORPORATE MARINE, COASTAL, AND FRESHWATER, PROTECTED AREAS INTO THE WORLD-WIDE NETWORK

Aquatic protected areas present a number of biological, administrative, and political, problems (IUCN, 1976). For reasons which are largely historical and administrative, the scientists, managers, administrators, and supporters, of aquatic habitats have been linked primarily with fisheries departments and have been rather separated from the traditional protected-areas community. The extension of present littoral areas into the aquatic environment may provide a means of bringing the fisheries managers into effective contact with terrestrial protected-area managers, to the benefit of both.

The Law of the Sea provides a framework for moving ahead, and IUCN has provided a set of principles, criteria, and guidelines, for the selection, establishment, and management, of marine and coastal protected areas (IUCN, 1980b). Furthermore, IUCN is currently de- veloping a system of marine biogeographic provinces for conservation purposes (Hayden et al., 1982), which will be used rather in the manner of the IUCN system of terrestrial biogeographic provinces (Udvardy, 1975) to assess coverage and focus priorities; based on this global system, more refined systems will need to be developed for use at the national and regional levels.

Perhaps the most important current activity of IUCN in this area is the preparation of a handbook on Managing Coastal and Marine Protected Areas, based on a series of the following 12 workshops held at the Bali Congress: The need for coastal and marine protected areas; The role of coastal and marine protected areas in the conservation of genetic resources; Classifying marine habitats for conservation purposes; Categories, criteria, and objectives, for coastal and marine protected areas; Principles of management planning for coastal and marine protected areas; Implementing management of coastal and marine protected areas; Selection and management of coral-reef protected areas; Selection and management of protected areas in estuaries, mangroves, and other coastal areas; Protected areas in the open seas; Protected areas in polar regions; Protecting island habitats; and The role of coastal and marine protected areas in the process of social and economic development.

\section{Objective 3:}

\section{TO IMPROVE THE ECOLOGICAL AND MANAGERIAL QUALITY} OF EXISTING PROTECTED AREAS

The first item discussed was the quantity of area required to attain conservation objectives; but clearly, quality is at least as important. The need is to develop and make available tools and guidelines for (a) evaluation of the ecological capacity of protected areas to maintain living resources, and (b) evaluation of area management to ensure that appropriate measures are being applied. This will include accurate documentation of the living resources contained in protected areas, the development of a system of reporting on protected areas under particular threat, and the development of concepts and methods which will lead to the application of scientific principles for management, while supporting the continuous analysis of conservation requirements for each area.

Using the strengthened conceptual foundation that is expected to be available as a result of the Bali Action Plan, IUCN seeks to support a systematic approach to the preparation of area and system management plans which provide for management and development to be in accordance with an appropriate range of conservation objectives. Guidelines for designing systems plans and area management plans will be prepared, and workshops will be held in priority countries on how to apply the guidelines on the ground.

A strong effort will be made to reinforce measures to reduce the external threats to protected areas, including design of model legislative and administrative measures, promotion of measures to relieve the pressures of local populations around protected areas, promotion of rehabilitation of degraded lands and the regeneration of dam- 
aged natural areas through reafforestation and other measures, and the preparation of manuals to guide planners, managers, and decision-makers, outside the protected-area system, on implementing integrated environmental approaches which will enhance the security of protected areas.

\section{Objective 4:}

\section{TO DEVELOP THE FULL RANGE OF WILDLAND MANAGEMENT CATEGORIES}

IUCN (1978) has provided a system of ten management categories, based on objectives for management (Table I); applications from around the world (e.g. Mosley, 1982) have indicated the value of this approach in expanding the range of management tools available for protecting natural habitats. While Categories I and II are well known and broadly applied, many of the other categories are still poorly understood in some countries. Pilot protected areas for each category need to be established, within each biogeographic realm, to demonstrate, alike to political leaders and local people, the importance of these alternatives for supporting social and economic development through approaches to sustainable resource management.

It is expected that having a range of protected-area options will provide enhanced protection to the strictlyprotected categories by removing people-pressures to areas which are able to sustain heavy visitor pressure. Countries will then be able to meet their responsibilities for the protection of Nature, while providing for human development on a sustainable basis.

The range of protected-area categories can address a broad spectrum of conservation issues and objectives, such that conservation can be identifiably linked to water availability, protein production, ecosystem productivity and diversity, production of pharmaceuticals, agriculture and livestock breeding, wood and wood products, science education, and the human environment in general. This will enable conservation to obtain a more important place at the development table. For example, a project to develop the water resources of a major river should include financial and technical support to conserve the upstream catchment even if the area is not of national park quality or contains a limited human population; one of the other categories, such as Cultural Landscape, may address the local situation quite adequately, whereupon a recognized form of conservation will be provided (IUCN, 1978).

The Bali Congress noted that, while National Parks and Nature Reserves must be strictly protected against efforts to exploit their natural resources for such purposes as timber cutting, mining, hydroelectric works, industrial facilities, commercial fishing, sport and commercial hunting, farming, and grazing of domestic animals, multiple-use management areas and other management régimes of intermediate intensity can nevertheless be established with advantage around the strictly-

TABLE I. Categories and Management Objectives of Protected Areas.*

I. Scientific Reserve/Strict Nature Reserve. To protect Nature and maintain natural processes in an undisturbed state in order to have ecologically representative examples of the natural environment available for scientific study, environmental monitoring, education, and for the maintenance of genetic resources in a dynamic and evolutionary state.

II. National Park. To protect natural and scenic areas of national or international significance for scientific, educational, and recreational, uses.

III. Natural Monument/Natural Landmark. To protect and preserve nationally significant natural features because of their special interest or unique characteristics.

IV. Managed Nature Reserve/Wildlife Sanctuary. To assure the natural conditions necessary to protect nationally significant species, groups of species, biotic communities, or physical features of the environment, where these require specific human manipulation for their perpetuation.

V. Protected Landscapes. To maintain nationally significant natural landscapes which are characteristic of the harmonious interaction of Man and land, while providing opportunities for public enjoyment through recreation and tourism within the normal life-style and economic activity of these areas.

VI. Resources Reserve. To protect the natural resources of the area for future use, and prevent or contain development activities that could affect the resource pending the establishment of objectives which are based upon appropriate knowledge and planning.

VII. Natural Biotic Area/Anthropological Reserve. To allow the way of life of [human] societies living in harmony with the environment to continue undisturbed by modern technology.

VIII. Multiple-use Management Area/Managed Resource Area. To provide for the sustained production of water, timber, wildlife, pasture, and outdoor recreation, with the conservation of Nature primarily oriented to the support of the economic activities (although specific zones may also be designed within these areas to achieve specific conservation objectives).

IX. Biosphere Reserve. To conserve for present and future use the diversity and integrity of representative biotic communities of plants and animals within natural ecosystems, and to safeguard the genetic diversity of species on which their continuing evolution depends.

$X$. World Heritage Site. To protect the natural features for which the area was considered to be of World Heritage quality, and to provide information for world-wide public enlightenment.

* Adapted from IUCN (1978). 
protected areas, to prevent them from becoming biologically impoverished 'islands' (IUCN, 1982e).

\section{Objective 5:}

TO PROMOTE THE LINKAGE BETWEEN PROTECTED-AREA MANAGEMENT AND SUSTAINABLE DEVELOPMENT

While Objective 4 provides a fairly simple and straightforward means of giving the protected area concept more flexibility in dealing with development issues, Objective 5 builds on this foundation to promote actively the linkage between protected areas and appropriate sustainable development. The first requirement is to work with governments and development assistance agencies to achieve the incorporation of protected-area considerations within development projects. Several examples of how protected areas can support development, and vice versa, were presented at the Bali Congress: Goodland (1982) outlined a number of cases where the World Bank has become involved with protected-area issues; Sumardja et al. (1982) described in detail a World Bank project involving Indonesia's Dumoga National Park; and Alwis (1982) showed how the US Agency for International Development is supporting the establishment of a network of protected areas in Sri Lanka, as part of a major water-resources development project in the Mahaweli Basin.

Additional conceptual development is still required to overcome the trepidation that some environmentalists feel about linking conservation with development interests. Policy guidelines and legal instruments need to be developed regarding the use of protected areas for research, environmental monitoring, and the collection of scientific materials, in order to ensure that protected-area values are not compromised.

A topic of particular concern is the use of protected areas as in situ gene-banks. It is quite clear that many protected areas contain genetic materials of considerable value to agriculturists, fisheries biologists, pharmacists, and foresters, and that the areas will have value as genebanks only as long as they are protected (Polunin, 1982; Prescott-Allen \& Prescott-Allen, 1982). Guidelines need to be developed to promote the value of protected areas as gene-banks, while allowing appropriate use of the genetic materials; zoning regulations, guidelines for collection, and appropriate financial measures, need to be designed and implemented in a few selected areas as pilot projects.

It is apparent that some people have already learned how to live in balance with their available resources. Sadly, these people are now considered 'primitive', even though their technology has sustained their society for hundreds of generations in a quite satisfying way. Few would suggest that such people should be kept in a 'backward' state if they desire to become part of modern 'television society', but it is important to document the traditional wisdom of these people before it is lost. Furthermore, if such 'traditional' people desire to maintain their way of life - and many of them actually enjoy a life where 20 hours of work a week produces enough of life's necessities to allow plenty of free time to play with their children, flirt with their mates, practise religious beliefs daily, and tell stories around the fire-then protected areas can provide a means by which they can do so (Category VII in Table I); in such cases, joint management arrangements should be made between protected-area authorities and societies which have traditionally-managed resources.

Finally, the linkage between protected areas and development will only work effectively if there is strong public support for the values of protected areas. Assistance - financial, technical, and informational- needs to be provided to voluntary conservation organizations for enlisting public support; youth activities in support of protected areas, such as tree-planting campaigns, work-study camps, field studies, and curricular elements, need to be promoted; and model interpretive programmes which emphasize the social and scientific values of protected areas - giving specific attention to issues of public concern - need to be widely disseminated and adapted to local conditions.

\section{Objective 6:}

TO DEVELOP THE FULL CAPACITY TO MANAGE PROTECTED AREAS

Linking protected-area conservation with development is a highly complex undertaking, requiring welltrained professionals at all levels. While a few countries have university curricula - even graduate programmes - dealing with protected-area management, there is still a major need for training seminars, courses, and workshops at the regional and local levels, for protectedarea managers. Existing regional and national training schools need to be strengthened, and new schools established. Schools such as the College of African Wildlife Management (Mosha \& Thorsell, 1982), the Ecole de Faune in Cameroon (Allo, 1982), and the Ciawi Conservation Training School in Indonesia (Duryat \& Lavieren, 1982), provide examples of the sort of training that is needed at the field level.

Most managers state that their area is 'run by the rangers', so local, in-service training programmes must be developed and implemented for all levels of protectedarea personnel. The ultimate objective is to promote the establishment and recognition of protected-area management as a professional career of vital relevance to society.

To help attain this objective, IUCN will publish in 1983 a manual on Training Protected-area Personnel, based on a series of 13 workshops at the Bali Congress. These were: Training, the key to developing the capacity to manage; The skills required to manage protected areas effectively; Manpower requirements for protected areas; Options for developing management capacity; Regional institutions for protected-area personnel; National training for protected-area field personnel; International professional training; Professional training at universities and colleges; Training at the senior policy level; Overcoming institutional obstacles to training; Sharing experience; Training the public; and The protected-area manager becomes a professional. 


\section{Objective 7:}

\section{TO DEVELOP ECONOMIC TOOLS FOR SUPPORTING PROTECTED} AREAS

Economic tools, such as cost-benefit analysis, high interest rates, discount rates, inflation, and many others, are sometimes used to weaken support for protected areas. By and large, protected-area managers have been poorly prepared to respond to economists who argue that their area should be allocated, for example, to logging. If protected areas are to continue to serve their functions, they must be philosophically competitive at the market-place.

The first step is to ensure that the intangible, non-fiscal values are strongly supported where it counts - at the high levels of government. The nongovernmental organizations need to be strengthened and encouraged in their lobbying efforts, and the general public needs to be mobilized in support of the ethical, aesthetic, and spiritual, values of protected areas.

At the same time, it seems wise to develop new economic tools for supporting protected areas. Moore (1982) has argued that a protected area which is designed and managed without consideration of its potential for use as a centre for human education, employment, research, and enjoyment, may be underutilized. Operating a protected area in such a way sows the seeds of potential future disaster. Conversely, by focusing on the ability of a protected area to contribute to human improvement, the resource manager demonstrates that the area is a fundamental link in local, national, and international, economics. By so doing, the manager increases his ability to obtain the freedom and the resources to maintain the protected area in a manner that both preserves the integrity of the ecosystems involved and satisfies the needs of the human population.

IUCN intends to carry out three major activities for developing the above economic tools: (1) Develop and distribute guidelines for the analysis of values associated with protected natural areas; (2) promote the quantification of values which relate conservation to development, including watershed protection, genetic resources, pollution control, soil formation, amelioration of climate, provision of recreation and tourism, and others of $\mathrm{Na}$ ture's services; and (3) develop concepts which relate ecology with economics, to promote a more consistent perspective than formerly existed for analysing the role of protected areas in sustaining development.

\section{Objective 8:}

TO IMPLEMENT AN EFFECTIVE INVENTORY AND MONITORING SERVICE

The Protected Areas Data Unit (PADU) and related components of the IUCN Conservation Monitoring Centre provide the data management capacity to support IUCN's field activities. PADU provides information on protected areas, guides the determination of priorities, and supports development agencies (both national and international) in relating the design of development projects to critical protected areas.
As part of UNEP's Global Environmental Monitoring Service (Gwynne, 1982), PADU links with other databases around the world to provide significantly more information on protected areas than has previously been available. Much of the information is computerized, though manual files are also maintained. It is expected that the unit will produce one realm-based directory each year; the first such volume, the IUCN Directory on Neotropical Protected Areas, was published very recently (IUCN, 1982a).

Perhaps more important, however, is the circumstance that PADU will also be able to: (a) respond to requests from development agencies, so that they can design their projects to enhance sustainable development and avoid adversely affecting sensitive areas; (b) provide information to international conservation agencies to help evaluate priority areas for allocation of scarce conservation funds; (c) tell plant breeders where wild ancestors of domestic agricultural crops can be found in protected areas in order to locate sources of genetic diversity for improving crops; (d) enable scientists to make comparisons over a wide range of habitat types, or over a complete species-range; and (e) inform governments on how protected areas are being managed in other countries, in order to enhance their own efforts and avoid repeating mistakes.

\section{Objective 9:}

\section{TO IMPLEMENT INTERNATIONAL COOPERATION MECHANISMS}

A wide range of international cooperation mechanisms already exists, but most of them are generally underutilized in support of protected areas. Ties must be strengthened with the Man and the Biosphere Programme, the Global Environmental Monitoring System, the World Heritage Convention, the Ramsar Convention on Wetlands, the Migratory Species Convention, and the various regional conservation conventions. In addition, countries should be encouraged to request appropriate allocations for protected areas in projects with FAO (Child, 1982), UNESCO (Droste, 1982), UNEP (Olembo, 1982), and the various bilateral sources available (Dalfelt, 1982; Simons, 1982; Wetterberg, 1982). There is also scope for cooperation with appropriate multinational corporations (Balzer, 1982).

Another matter which was mentioned at Bali, and which is receiving increased international attention, is the development of mechanisms for the fair sharing of costs and benefits associated with protected areas management, both among nations and between protected areas and adjacent communities. The World Heritage Convention is one important means of sharing the costs, but it covers only relatively few areas and its budget is still small. Perhaps the Law of the Sea Convention will lead to breakthroughs for marine areas; but countries that are using their budgets to conserve resources for the benefit of all mankind also need to be appropriately supported.

The Bali Action Plan is itself an international cooperation mechanism which, if fully implemented, would go a long way towards helping protected areas to earn the 
support which is commensurate with their contribution to society's well-being.

\section{Objective 10:}

TO DEVELOP AND IMPLEMENT A GLOBAL PROGRAMME TO SUPPORT PROTECTED-AREA MANAGEMENT

Based on the preceding 9 objectives, regional action programmes should be designed and implemented to ensure practical accomplishments on the ground, taking into account relevant cultural and institutional diversity, and also responsiveness to local needs. The IUCN network provides an ideal mechanism for initiating such action programmes, in cooperation with national governments, UNEP, FAO, UNESCO, and the World Wildlife Fund.

Another contribution that IUCN can make is by the continued provision of technical and scientific guidance through the publication of a series of documents on practical subjects of global concern to protected-area management. The first such publication will be the Proceedings of the Bali Congress, followed by a manual on Managing Protected Areas, based on a series of 12 workshops held at Bali as follows: Policies to meet expanding needs; Categories, criteria, and objectives, of protected areas; The biogeographical basis for protected-area systems; The legal and administrative basis for management; Protected areas and regional planning; Socio-economic factors in managing protected areas; Developing principles of resource management; Management planning; Implementing management; Determining effective management; International cooperation in management of protected areas; and Ensuring that the right message reaches the right audiences.

It is apparent that all protected areas around the world share problems, concerns, and opportunities. A communications network involving the global community responsible for, or supporting, protected areas would ensure the flow of information and support the identity of the protected-area profession. The World National Parks Congress expressed its strong support for the development of such a communications network.

\section{CONCLUSION}

The Bali Action Plan is a revolutionary advance in linking the conservation of protected areas with social and economic development; no matter what the future may hold in store, it is apparent that the natural resources contained in protected areas are a sound investment. The ten objectives of the Bali Action Plan, if broadly supported by governments and conservation agencies and implemented together in a reasonably coherent way, can help ensure that protected-area resources are conserved to form an inseparable part of the modern human heritage.

In a period of shrinking budgets, global inflation, and widespread pessimism about the future, governments must still find the resources to support their protected areas; many countries, including some with the lowest per caput GNP, are continuing to expand their protectedarea systems at a rapid rate, and will need the appropriate resources to finance this expansion. It is much to be hoped that the Bali Action Plan will help demonstrate to governments and international assistance agencies that the conservation of protected areas should be considered just as important as national defence, education, communication, and public health, when priorities for limited budgets are being considered.

With greatly increased public realization of their responsibilities for helping to ensure that social and economic development meets the real needs of human societies, protected areas can be expected to receive a significantly increased amount of support from governments, international development agencies, and local people.

The Bali Action Plan concludes: 'Thus, as those professionally involved in protected-area planning, management, research, and promotion, we go forth from Bali with the conviction that the contribution of national parks and protected areas to people and to life on Earth is fundamental if sustainable welfare, ways of life, and peace, are to be attained; with the vision of an emerging enterprise as ambitious and vital as any in the history of humanity; and a commitment to solidarity with our children and generations yet unborn, that they shall inherit this unique, small, and fragile, planet rich in options for determining their own destiny.'

\section{SUMMARY}

In order to ensure that the full range of species and natural ecosystems continue to form part of the human habitat, national parks and other types of protected areas must be better designed and managed than is usually the case at present. While IUCN has a long history of involvement in protected areas, often in cooperation with UNESCO, the World Wildlife Fund, and UNEP, the World National Parks Congress (held in Bali, Indonesia, during 11-22 October 1982) marked a major turningpoint in promoting protected areas as part of the social and economic development process. In this approach, the Congress provided ways and means for the philosophy of the World Conservation Strategy (1980) to be put into action on the ground.

A ten-point 'Bali Action Plan' was developed, comprising the following: (1) To establish by 1992 a worldwide network of national parks and protected areas exemplifying all terrestrial ecological regions; (2) to incorporate marine, coastal, and freshwater, protected areas into the world-wide network; (3) to improve the ecological and managerial quality of existing protected areas; (4) to develop the full range of wildland management cagegories; (5) to promote the linkage between protectedarea management and sustainable development; (6) to develop the full capacity to manage protected areas; (7) to develop economic tools for supporting protected areas; (8) to implement an effective inventory and monitoring service; (9) to implement international cooperation mechanisms; and (10) to develop and implement a global programme to support protected-area management.

The implementation of the Bali Action Plan will require the cooperation of international agencies, non- 
governmental conservation organizations, and national protected-area management agencies. With the implementation of the Plan, protected areas will assume greatly-increased responsibilities for helping to ensure that social and economic development meets the real needs of human societies, and that human societies meet their responsibilities to Nature. This expanded role should lead to significantly greater support for protected areas from governments, international development agencies, and local people.

\section{REFERENCES}

Adams, Alexander B. (1964). First World Conference on $\mathrm{Na}$ tional Parks. US Department of the Interior, Washington, DC, USA: xxxiii + 471 pp., illustr., maps.

Allo, ANDREw (1982). School for the Training of Wildlife Specialists at Garoua, Cameroon. Paper presented at World National Parks Congress, Bali, Indonesia: 6 pp., preprint.*

ALwIS, LyN de (1982). River-basin Development and Protected Areas in Sri Lanka. Paper presented at World National Parks Congress, Bali, Indonesia: 8 pp., preprint.*

Balzer, Leroy (1982). Development and Conservation: Coexistence through Rational Planning. Paper presented at World National Parks Congress, Bali, Indonesia: 5 pp., preprint.*

BARR, TERRY N. (1981). The world food situation and global grain prospects. Science, 214, 1087-95.

CARP, ERIK (1980). Directory of Wetlands of International Importance in the Western Palearctic. IUCN/UNEP, Gland \& Nairobi: 506 pp., maps.

ChILd, GIL (1982). FAO and Protected Area Concerns: Promoting Increased Support. Paper presented at World National Parks Congress, Bali, Indonesia: 22 pp. (typescr.).

DALFELT, ARNe (1982). The Role of International Development Agencies in Promoting Effective Management of Protected Areas. Paper presented at World National Parks Congress, Bali, Indonesia: 16 pp., preprint.*

Dingwall, Paul (1982). New Zealand: Saving some of everything. Ambio, 11(5), pp. 296-301.

Droste, BerNd VON (1982). How UNESCO's Man and the Biosphere Programme is Contributing to Human Welfare. Paper presented at World National Parks Congress, Bali, Indonesia: $28 \mathrm{pp}$. (typescr.).*

DURyat, MOHAMmED \& LAVIEREN, BART VAN (1982). Indonesia's Experience in Training Protected Areas Personnel. Paper presented at World National Parks Congress, Bali, Indonesia: 17 pp., preprint.*

Ehrlich, Paul [R.] \& Ehrlich, AnNe [H.] (1981). Extinction: The Causes and Consequences of the Disappearance of Species. Random House, New York, NY, USA: xiv + 305 pp.

EIDSVIK, HAROLD K. (1980). National Parks and other protected areas: Some reflections on the past and prescriptions for the future. Environmental Conservation, 7(3), pp. 185-90.

Elliott, Sir Hugh (1974). Second World Conference on $\mathrm{Na}$ tional Parks. IUCN, Morges, Switzerland: 504 pp., illustr.

GOODLAND, RoBERT [S.A.] (1982). Environmental Requirements of the World Bank, Including Wildland Conservation. Paper presented at World National Parks Congress, Bali, Indonesia: 52 pp. (mimeogr.).*

Gwynne, Michael D. (1982). The Global Environment Monitoring System (GEMS) of UNEP. Environmental Conservation. $9(1)$, pp. 35-41, 4 figs.

Harrison, Jeremy, Miller, Kenton R. \& McNeely, JefFrey A. (1982). The world coverage of protected areas: Development goals and environmental needs. Ambio, 9(5), pp. $238-45$.

Haydén, B.P., Dolan, Robert \& Ray, G. Carleton (1982). $A$ System of Marine Biophysical Provinces for Conservational
Purposes. Paper presented at World National Parks Congress, Bali, Indonesia: 15 pp., preprint.*

IUCN (1961). The United Nations List of National Parks and Equivalent Reserves. IUCN, Morges, Switzerland: [not available for checking.]

IUCN (1971). United Nations List of National Parks and Equivalent Reserves (2nd edition). IUCN Publ. (N.S.) 15, \& Hayez, Brussels, Belgium: 601 pp., illustr.

IUCN (1975). World Directory of National Parks and Other Protected Areas (Vol. I). IUCN, Morges, Switzerland: (looseleaf, approx. $350 \mathrm{pp}$.).

IUCN (1976). An International Conference on Marine Parks and Reserves. IUCN Publ. (N.S.) 37, $131 \mathrm{pp}$.

IUCN (1977). World Directory of National Parks and Other Protected Areas (Vol. II). IUCN, Morges, Switzerland: (looseleaf, approx. 400 pp.).

IUCN (1978). Categories, Objectives and Criteria for Protected Areas. IUCN, Morges, Switzerland: $26 \mathrm{pp}$.

IUCN (1979). The Biosphere Reserve and its Relationship to Other Protected Areas. IUCN, Morges, Switzerland: 19 pp.

IUCN (1980a). 1980 United Nations List of National Parks and Equivalent Reserves. IUCN, Gland, Switzerland: $121 \mathrm{pp}$., map.

IUCN (1980b). Principles, Criteria and Guidelines for the Selection, Establishment and Management, of Mediterranean Marine and Coastal Protected Areas. UNEP, Nairobi, Kenya: 35 pp. (mimeogr.).

IUCN $(1980 c)$. Conserving Africa's Natural Heritage: The Planning and Management of Protected Areas in the Afrotropical Realm. IUCN, Gland, Switzerland: $230 \mathrm{pp}$.

IUCN (1981). Conserving the Natural Heritage of Latin America and the Caribbean: The Planning and Management of Protected Areas in the Neotropical Realm. IUCN, Gland, Switzerland: 329 pp.

IUCN (1982a). IUCN Directory of Neotropical Protected Areas. IUCN, Gland, Switzerland: xxv. + 436 pp., maps.

IUCN (1982b). The World's Greatest Natural Areas: An Indicative Inventory of Natural Sites of World Heritage Quality. IUCN, Gland, Switzerland: 69 pp., illustr., maps.

IUCN (1982c). 1982 United Nations List of National Parks and Protected Areas. IUCN, Gland, Switzerland: $154 \mathrm{pp.}$

IUCN (1982d). The World National Parks Congress. IUCN, Gland, Switzerland: $131 \mathrm{pp}$.

IUCN (1982e). Recommendations from the World National Parks Congress. IUCN Bulletin (N.S.), 13(10-11-12), 8 pp. (insert).

IUCN (1982f). The Bali Action Plan. IUCN, Gland, Switzerland: 28 pp., preprint.*

LAUSCHE, Barbara (1981). Guidelines for protected area legislation. IUCN Env. Policy Law Paper 16, 108 pp.

MACARTHUR, R. \& WiLson, E.O. (1967). The Theory of Island Biogeography. Princeton University Press, Princeton, New Jersey, USA: xi +203 pp.

MoORE, MiChael (1982). Economic Concepts and Methods for Valuing Protected Natural Areas. Paper presented at World National Parks Congress, Bali, Indonesia: 13 pp., preprint.*

Mosha, G.T. \& Thorsell, JAMEs W. (1982). Training Wildlife Managers in East Africa. Paper presented at World National Parks Congress, Bali, Indonesia: 9 pp., preprint.*

Mosley, J.G. (1982). Protected Areas and Environmental Planning in Australia. Paper presented at World National Parks Congress, Bali, Indonesia: 14 pp., preprint.*

*It is understood that these papers will be published by or through IUCN in a book of proceedings of the Bali Congress. --Ed. 
Myers, Norman (1980). The Sinking Ark: A New Look at the Problem of Disappearing Species. Pergamon Press, Oxford, England, UK: xiii + 305 pp., 9 tables.

Olembo, Reuben (1982). UNEP and Protected Area Concerns. Paper presented at World National Parks Congress, Bali, Indonesia: $24 \mathrm{pp}$. (typescr.).*

Polunin, Nicholas V.C. (1982). The Role of Protected Areas in Conserving Coastal and Marine Genetic Resources. Paper presented at World National Parks Congress, Bali, Indonesia: 16 pp., preprint.*

Poore, Duncan \& Gryn-Ambroes, Paule (1980). Nature Conservation in Northern and Western Europe. IUCN/UNEP, Gland, Switzerland, \& Nairobi, Kenya: 408 pp., maps.

Prescott-Allen, Robert \& Prescott-Allen, Christine (1982). Park Your Genes: Managing Protected Areas for Genetic Conservation. Paper presented at World National Parks Congress, Bali, Indonesia: 8 pp., preprint.*

Simons, Ross (1982). Ten Years Later: The Smithsonian International Experience Since the Second World Parks Congress. Paper presented at World National Parks Congress, Bali, Indonesia: 11 pp., preprint.*
Sumardja, EfFEndi, TARmudi \& Wind, JAN (1982). Nature Conservation and Rice Production in Dumoga, North Sulawesi. Paper presented at World National Parks Congress, Bali, Indonesia: 7 pp., preprint.*

UDVARDY, MIKLOS (1975). A classification of the biogeographic provinces of the world. IUCN Occas. Paper, 7, pp. 1-44.

WetTER Berg, Gary (1982). The Exchange of Wildland Technology: A Management Agency Perspective. Paper presented at World National Parks Congress, Bali, Indonesia: 11 pp., preprint.*

World Conservation Strategy (1980). World Conservation Strategy: Living Resource Conservation for Sustainable Development. IUCN-UNEP-WWF (obtainable from IUCN, Avenue du Mont-Blanc, 1196 Gland, Switzerland: pack of ca 50 unnumbered pp., illustr., in stiff paper folder).

* It is understood that these papers will be published by or through IUCN in a book of proceedings of the Bali Congress. -Ed. 